\title{
Proline and ions accumulation in four Passiflora species under water-saline stress
}

\author{
Alejandro Hurtado-Salazar ${ }^{*}$, Danielle Fabiola Pereira da Silva², Nelson Ceballos-Aguirrel, \\ John Ocampo ${ }^{3}$, Claudio Horst Bruckner ${ }^{4}$
}

\author{
IUniversity of Caldas, Manizales, Colombia \\ 2Federal University of Goiás, Goiania, Brazil \\ 3National University of Colombia, Palmira, Colombia \\ 4Federal University of Viçosa, Viçosa, Brazil \\ *Corresponding author, e-mail: alhuza@gmail.com
}

\begin{abstract}
Water-saline stress is one of the factors limiting growth and crop production, with the induction of morphological, structural and metabolic changes in higher plants. This study aimed to evaluate the response of four species with ten accessions of Passiflora to saline stress and drought stress, and the accumulation of proline and content of cationic macronutrients and their relationships with sodium. The plants were grown under controlled conditions for seven months, watered with nutrient solution with additions of $\mathrm{NaCl}(100 \mathrm{mM})$ to achieve the desired conductivities $(1.5,2.5$, 4.0 , and $5.5 \mathrm{dS} \mathrm{m}^{-1}$ ) and constant substrate humidity of $100 \%, 66 \%$ and $33 \%$. The concentrations of $\mathrm{Na}^{+}, \mathrm{K}^{+}, \mathrm{Ca}^{++}, \mathrm{Mg}^{++}$and proline in the leaves were determined. Proline accumulation increased in salinized plants, especially in young leaves. Proline increase was evident in accessions tolerant and moderately tolerant to salinity. These results indicate that tolerance to salinity and water stress in Passiflora relates to an improved ability to exclude sodium and greater ability to accumulate proline for osmotic adjustment. The increased salinity of the nutrient solution increased sodium contents, relations $\mathrm{Na}^{+} / \mathrm{Ca}^{++}, \mathrm{Na}^{+} / \mathrm{Mg}^{++}, \mathrm{Na}^{+} / \mathrm{K}^{+}$, and decreased $\mathrm{Ca}^{++}, \mathrm{Mg}^{++}$and $\mathrm{K}^{+}$levels, reflecting the nutritional imbalance caused by progressive saline stress.
\end{abstract}

Keywords: $\mathrm{NaCl}$, abiotic stress, stress physiology, tolerance

\section{Introduction}

The passionfruit crops have contributed

to regional development in different countries such as Colombia, Ecuador and Brazil, where the availability of humidity is a constraint on development due to low rainfall in cultivable lands, thus salts concentration on soil is high. In most cultivated plants, sensitivity to salinity and drought conditions are associated with the inability to prevent and/or, tolerate high salt concentrations. This way, it is considered that the ability of salt exclusion is an important mechanism of tolerance (Garcia \& Medina, 2009). Similarly, salt tolerance has been associated to the ability of compartmentalization of toxic ions in mature

leaves or organs of lower sensitivity (Sacala et al., 2016) and the maintenance of selectivity on the absorption and transport of $\mathrm{K}^{+}$in the presence of $\mathrm{Na}$ (Coskun et al., 2016).

The ability to ensure the osmotic adjustment and guarantee the water flow in cells is an important factor for plants exposed to salinity and drought (Sacala et al., 2016). The most important inorganic ions for osmotic adjustment are $\mathrm{K}^{+}, \mathrm{Na}^{+}$and $\mathrm{Cl}^{-}$, but also other organic solutes are important such as soluble sugars and proline (Abdel, 2007). Typically, these solute levels increase when plants undergo salt stress and drought (Jian et al., 2016). Although there is a considerable amount of research 
related to water stress, mainly oriented to water relations, photosynthesis and accumulation of different organic metabolites, the metabolic pathways where stress harms the plant are still not well known nor are the coping mechanisms used by plants to survive these adverse conditions (Rizwan et al., 2015).

With the objective of reducing the negative effects of the limited availability of humidity, it is convenient to select plant species or genotypes following different indicators of water stress tolerance (Jian et al., 2016). Physiological indicators such as proline concentration, carbooidrates and antioxidant enzymes provide information which indicates that a plant species have the adatpations potential to water-saline stress environments and thus fulfill their life cycle. Higher plants, in relation to agronomic indicators (plant height, root length and leaf area), are subjected to the selection of complex components such as drought tolerance (Kaur \& Zhawar, 2015). Eleven elite accessions were considered of four Passiflora species of commercial interest, previously assessed, characterized and selected in several producing regions of Colombia, based on the improvement program of Ocampo et al. (2013), and different gene banks from various institutions, highlighting the need of identifying an accession of Passifloraceae family capable to tolerate stressful conditions. However, there is little information on the physiological mechanisms that determine the differential behavior of Passifloraceae. The objective of this study was to determine the role of the ability for $\mathrm{Na}+$ exclusion, compartmentalization of ions inside the leaves, relative selectivity of $\mathrm{K}+$ in the presence of $\mathrm{Na}+$ and accumulation of proline for osmotic adjustment in the differential sensitivity to salinity in Passiflora species.

\section{Materials and Methods}

The experiment was conducted in hydroponic conditions in a greenhouse of the Department of Agricultural Production at the University of Caldas, Manizales, Colombia. Manizales County is in the coffee triangle, in the center of the department of Caldas, with coordinates $5^{\circ} 03^{\prime} 23.31^{\prime \prime} \mathrm{N}$ and $75^{\circ} 29^{\prime} 41.56^{\prime \prime} \mathrm{W}$, altitude of $2,130 \mathrm{~m}$, with average outside temperature of $18^{\circ} \mathrm{C}$, average annual rainfall of $2,000 \mathrm{~mm}$ and relative humidity of $78 \%$.

Eleven elite accessions from four Passiflora species of commercial interest were used, with prior characterization and evaluation of genetic variability degree of passionfruit cultivated in Colombia, as a basis for a breeding program (Ocampo et al., 2013), and from different gene banks from various institutions (Table 1). 240 seeds of each accession were sown, germinated in a hydroponic bed containing rice husk as substrate, maintained constantly moist until the time of transplantation. At 15 days of germination, 54 seedlings were selected from each access, ensuring the greatest possible uniformity for root system. Subsequently, the seedlings were transferred to hydroponic beds with $6 \mathrm{~m}$ of length and $1.2 \mathrm{~m}$ of width to ensure irrigation according to the treatments (percentage of water saturation $100 \%, 66 \%$ and $33 \%$ and saturation levels of salts

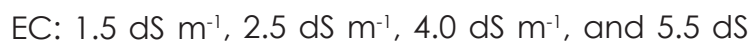
$\mathrm{m}^{-1}$ ) applied according to the experimental design. The conduction system in vertical shoot (thread) was used, with galvanized wire No. 12 , at $2 \mathrm{~m}$ from the floor of the hydroponic bed of the greenhouse. The seedlings were staked to a single stem, with once a week pruning of side branches. Once the main stem overreached the wire by $20 \mathrm{~cm}$, these were bent downward, forming a loop. Secondary and tertiary branches were maintained.

Eight days after transplantation, the treatment of salinization with application of $\mathrm{NaCl}$ $\left(100 \mathrm{~mol} \mathrm{~m}^{-3}\right)$ was started to obtain the desired electrical conductivity in each treatment. Irrigation was carried out according to each of the predetermined treatment, and a control treatment was maintained in which the plants were watered with nutrient solution without addition of salts. The experimental design was a completely randomized in an array of subdivided plots, where the plot was the percentage of water saturation in relation to the requirement of the crop $(100 \%, 66 \%$ and $33 \%)$ and the subplot consisted of salt saturation levels (EC: $1.5 \mathrm{dS} \mathrm{m}^{-1}$,

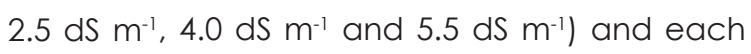
sub-subplot contained the 11 accessions of Passiflora in a completely randomized array with 
Table 1- Commercial Passiflora Accessions from different gene banks in Colombia selected to evaluate abiotic stresses (salinity and drought)

\begin{tabular}{|c|c|c|c|}
\hline Species & Procedence & Identification & Classification' \\
\hline P. edulis f. edulis Sims & Colombia-UNAL & m2-Cumbia2014 & MT \\
\hline P. maliformis L. & Colombia-UNAL & m3-Cholupa2014 & $S$ \\
\hline P. edulis f. flavicarpa D. & Colombia-UNAL & m4-Calfla04/2014 & $S$ \\
\hline P. edulis f. flavicarpa D. & Colombia-UNAL & m6-Caufla01/2014 & S \\
\hline P. edulis f. flavicarpa D. & Colombia-UNAL & m7-Tolfla02/2012 & $S$ \\
\hline P. edulis f. flavicarpa D. & Colombia-UNAL & m9-Atlafla01/2011 & $S$ \\
\hline P. edulis f. flavicarpa D. & Colombia-UNAL & ml1-Valfla10/2010 & $\mathrm{T}$ \\
\hline P. edulis f. flavicarpa D. & Colombia-UNAL & m12-Valluna/2014 & MT \\
\hline P. edulis f. flavicarpa D. & Colombia-CIAT & m13-Huifla07/2014 & $\mathrm{T}$ \\
\hline P. edulis f. flavicarpa D. & Colombia-UCAL & m14-Calfla01/2015 & MT \\
\hline P. tarminiana $C \&$ B & Colombia-UCAL & m15-Calmol01/2015 & $\mathrm{T}$ \\
\hline
\end{tabular}

five replications, where the experimental unit consisted of a single plant.

The modified universal nutrient solution of Hoagland \& Arnon (1950) by Niu et al. (2015) was used. To ensure the salinity of the treatment, each solution was brought to a value of CE: $1.5 \mathrm{dS} \mathrm{m-1}$; $2.5 \mathrm{dS} \mathrm{m}-1 ; 4.0 \mathrm{dS} \mathrm{m}-1$; and $5.5 \mathrm{dS} \mathrm{m}-1$, with the addition of reactive level sodium chloride $199.9 \%$ purity). To evaluate the interaction between the percentage of water saturation and salinity, different electrical conductivity treatments were added (1.5 dS m-1, $2.5 \mathrm{dS} \mathrm{m}-1,4.0 \mathrm{dS} \mathrm{m}-1$, and $5.5 \mathrm{dS} \mathrm{m}-1$ ) to percentages of water of $100 \%, 66 \%$ and $33 \%$ for each of the experimental units of the accessions evaluated.

The determination of proline and ions were performed at 150 and 250 days, respectively, after the start of the water-saline stress treatments in three randomly selected plants per treatment, in which third leaves fully expanded were sampled, excluding the midrib. After collecting the samples, these were processed immediately.

Determination of proline: proline concentration in the samples obtained on July 30, 2015 was determined according to the method proposed by Marin et al. (2010): $0.5 \mathrm{~g}$ of fresh leaves were weighted, macerated in $5 \mathrm{ml}$ of sulfosalicylic acid at $3 \%$, with vigorous stirring for $60 \mathrm{~min}$ and finally centrifuged at $6000 \mathrm{rpm}$ for $30 \mathrm{~min}$. A $2 \mathrm{ml}$ aliquot of supernatant, to which $1.0 \mathrm{ml}$ of ninhydrin acid, $1.0 \mathrm{ml}$ of glacial acetic acid and $1.0 \mathrm{ml}$ of acetic acid were added, was stirred for 20 seconds, then incubated for $60 \mathrm{~min}$ at $100^{\circ} \mathrm{C}$, followed by a cold bath; and $3 \mathrm{ml}$ of toluene were added with vigorous stirring. Then, absorbance was read at $520 \mathrm{~nm}$.
A calibration curve was made using six dilutions of the increasing concentrations $(0.333$ to 13.300 $\mu \mathrm{M})$ from the rapier proline solution $(40 \mu \mathrm{M})$. These solutions were subjected to spectrophotometric analysis (Nanocolor UV/vis). All determinations were performed in triplicate.

Once the samples were obtained, they were dried for 48 hours at $60^{\circ} \mathrm{C}$ in a forced air convection oven (Thelco-Model 6557). The dried material of each sample was milled in a cyclone mill with $1 \mathrm{~mm}$-diameter mesh (Foss-Cyclotec 1093) and it was used to define the concentration of $\mathrm{Na}^{+}, \mathrm{K}^{+}$and $\mathrm{Ca}^{++}$. The breakdown of the percentage of ash, humidity and dry matter was conducted by AOAC (2016) method. The quantification of leaf $\mathrm{Na}^{+}, \mathrm{K}^{+}, \mathrm{Ca}^{++}$was carried out by atomic absorption (Thermo line 969). The concentration of ions in percentage in 100 $\mathrm{g}$ of dry leaves and the relations of $\mathrm{K}^{+} / \mathrm{Na}^{+}$were also calculated. For ions determination, the accession m 13 was not considered due to loss of the experimental unit. For data statistical analysis , analysis of variance and mean comparison tests (Duncan test) were performed, using the SAS (Statistical Analysis System, 2013) statistical package.

\section{Results and Discussion}

According to Figure 1, the linearity of the data is evident ( $R 2=0.933$ ). The data of the slope and the equation intercept of the line were used to calculate the concentration of proline in the different samples.

According to the interaction of water and saline stress and the different levels of each of these stressors, it was found that the condition 


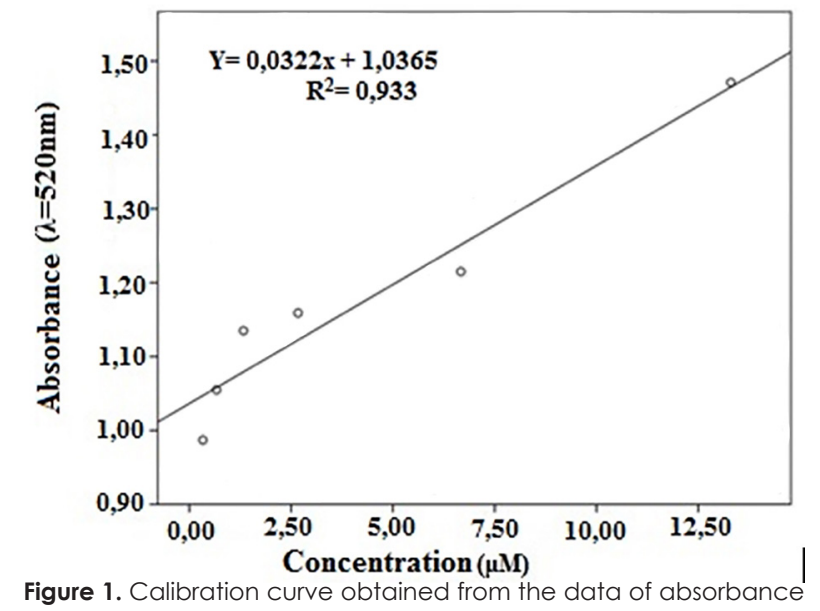

and concentration of proline dilutions.

of high salt (5.5 dS m-1) promotes greater proline accumulation (Table 2). The amino acid proline is a metabolite that accumulates in plants most often in conditions of drought and saline stress, considering that this is involved in the mechanism of stress resistance (Herrera et al., 2012).

The concentrations of free proline in ideal conditions of humidity and salinity $1100 \%$ and $1.5 \mathrm{dS} \mathrm{m}^{-1}$ ) were undetectable according to the calibration curve; likewise, these were undetectable in conditions of $100 \%$ humidity and $4.0 \mathrm{dS} \mathrm{m}^{-1}$. According to Marijuan \& Bosch (2013), this mechanism of osmotic adjustment (proline accumulation) provides protection during short stress periods and it is important when conditions normalize soon, not being the concentrations of free proline favored by the increase of salinity of $4.0 \mathrm{dS} \mathrm{m}^{-1}$ and $100 \%$ humidity (Figures $2 \mathrm{~A}$ and $2 \mathrm{E})$. The accessions evaluated presented higher proline content from the substrate with $66 \%$ and $33 \%$ humidity, and electrical conductivity of 5.5 dS $\mathrm{m}^{-1}$. There was significant difference between the concentrations of proline found for low $(2.5$ dS $\mathrm{m}^{-1}$ ) and high (5.5 dS $\mathrm{m}^{-1}$ ) salinity levels, a behavior similar to those found for intermediate (66\%) and low (33\%) humidity. Accessions m15, $m 12, m 9, m 6$ and $m 3$, respectively, showed a higher concentration of free proline in conditions of high salinity $\left(5.5 \mathrm{dS} \mathrm{m}^{-1}\right)$ and low humidity (33\%).

For intermediate conditions of humidity (66\%), accessions $\mathrm{m} 15, \mathrm{~m} 13, \mathrm{ml} 2, \mathrm{~m} 7$ and $\mathrm{m} 2$ showed the highest concentration of proline, respectively. As for the conditions of $100 \%$ humidity and salinity of $5.5 \mathrm{dS} \mathrm{m}^{-1}$, accessions $\mathrm{m} 15$, $\mathrm{m} 14, \mathrm{~m} 13, \mathrm{~m} 11, \mathrm{~m} 9, \mathrm{~m} 6$ and $\mathrm{m} 4$ showed higher concentration of free proline with electrical conductivity of $5.5 \mathrm{dS}^{-1}$, respectively, not as pronounced increase of proline concentration with the decrease electrical conductivity.

The highest leaf proline concentration corresponded to potentially sensitive accessions (m3, m4, m6, m7, m9). The presence of higher levels of this aminoacid in leaf tissue was not reflected in a lower reduction in the growth of this genotype, indicating that the accumulation of this amino acid in these accessions is more a sensor of the damage caused by the toxic effects of the salts than a tolerance mechanism. According to

Table 2. Effect of humidity and salinity in proline content ( $\left.\mathrm{mg} \mathrm{g}^{-1}\right)$ in 11 accessions of Passiflora in Manizales, Caldas, Colombia.

\begin{tabular}{cc}
\hline Condition & Proline $\left(\mathrm{mg} \mathrm{g}^{-1}\right)$ \\
\hline Unit (\%) & $-6.2146^{\mathrm{ND}}$ \\
\hline 100 & $-0.7278^{\mathrm{ND}}$ \\
66 & $-3.1153^{\mathrm{ND}}$ \\
\hline 33 & \\
\hline Salinity $\left(\mathrm{dS} \mathrm{\textrm {m } ^ { - 1 }}\right)$ & $-25.5497^{\mathrm{ND}}$ \\
\hline 1.5 & $-7.7759^{\mathrm{ND}}$ \\
2.5 & $-3.5942^{\mathrm{ND}}$ \\
4.0 & 8.590 \\
5.5 & \\
\hline ND Equivalent negative values undetectable, according to the calibration curve (Figure 1).
\end{tabular}



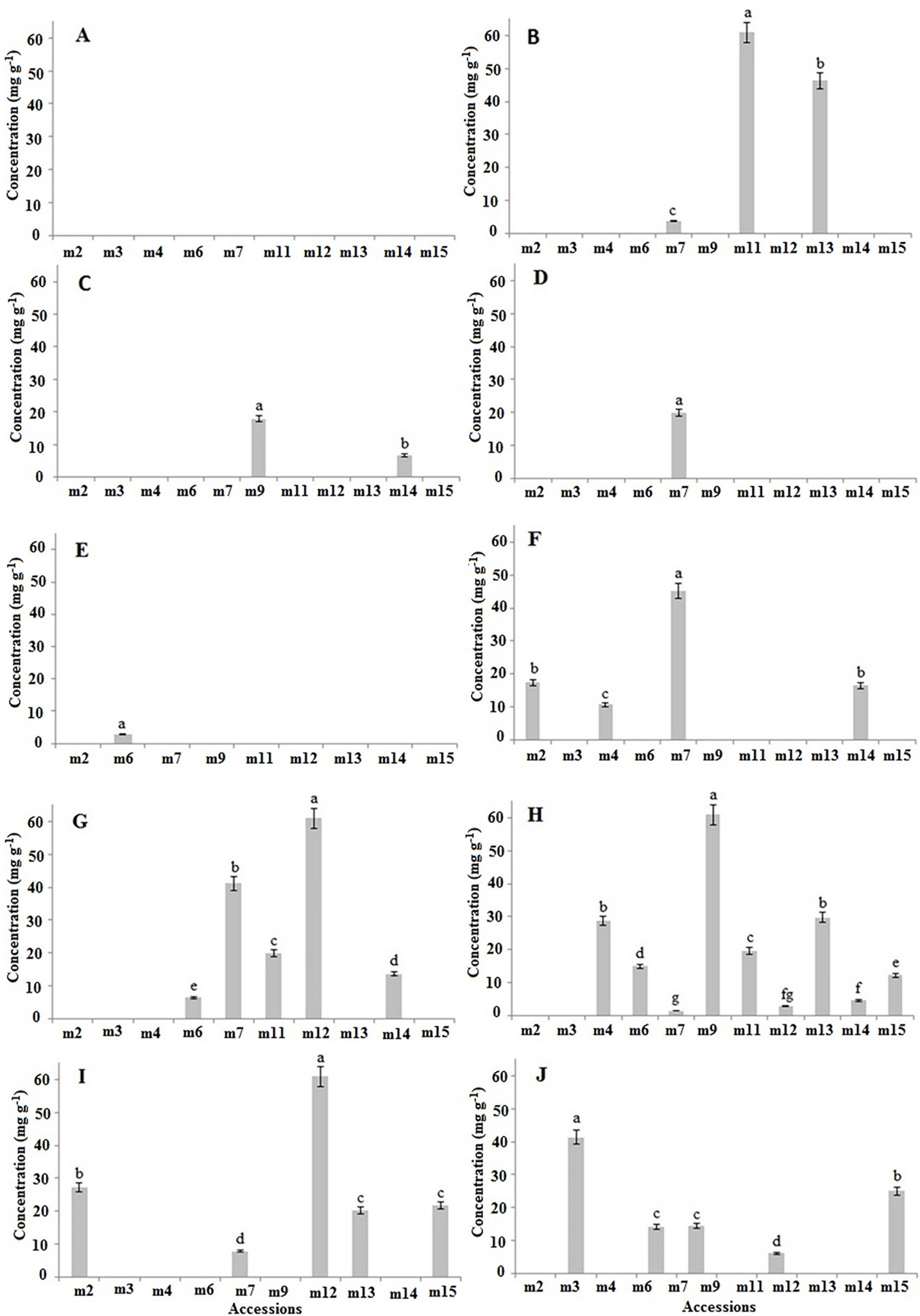

Figure 2. Proline concentration, in mg g-1, of ten Passiflora accessionsunder salinity and drought stress, at 150 days after transplanting (DAT) in Manizales, Caldas, Colombia. Statistical index: columns are median \pm standard deviation $(n=33$ ) and mean compared by Duncan's test $(P<0.05)$. *The values followed by different letters differ significantly $(P<0.05)$ according to Duncan's test. ND Equivalent negative values undetectable according to the calibration curve. A. Salinity 1.5 dS m-1 and $100 \%$ humidity; B. Salinity $2.5 \mathrm{dS} \mathrm{m}-1$ and $100 \%$ humidity; C. Salinity $2.5 \mathrm{dS} \mathrm{m-1}$ and $66 \%$ humidity; D. 2.5 Salinity dS m-1 and $33 \%$ humidity; E. Salinity $4.0 \mathrm{dS} \mathrm{m}-1$ and $100 \%$ humidity; F. Salinity $4.0 \mathrm{dS} \mathrm{m}-1$ and $66 \%$ humidity; G. Salinity 4.0 dS m-1 and $33 \%$ humidity; H. Salinity $5.5 \mathrm{dS} \mathrm{m}-1$ and $100 \%$ humidity; I. Salinity $5.5 \mathrm{dS} \mathrm{m}-1$ and $66 \%$ humidity; and J. Salinity $5.5 \mathrm{dS} \mathrm{m}-1$ and $33 \%$ humidity. 
Garcia \& Medina (2009), in sensitive genotypes of cane at high electrical conductivities of 15.5 and $8.5 \mathrm{dS} \mathrm{m}^{-1}$ respectively, the presence of higher proline levels in leaf tissue was not reflected in a lower growth reduction. Proline is one of the compatible solutes that accumulates in higher amounts under stress conditions if compared to other amino acids, indicating that under these conditions, proline is synthesized in "source" cells and transported to "demand" tissues known as growth points, using energy provided by organic compounds.

Herrera et al. (2012) documented that, in response to some sort stress (drought, salinity or cold), vacuolated cells from the root tip accumulate high proline levels in chloroplast stroma and in the cytoplasm, while other solutes (sugars, organic acids, potassium) accumulate in the vacuole. Since the cytoplasm is a small fraction of the volume of the cells, local concentrations of local proline in the cytoplasm can be much higher than the volume level of the tissue (Versleus \& Sharma, 2010). Moreover, it has also been recognized that proline protection functions can be shared with specialized compatible solutes that accumulate during stress, such as glycine, betaine and sugar alcohols.

Sensitive accessions to water-saline stress ( $m 2, m 3, m 4, m 6, m 12, m 13$ and $m 14)$, specifically accessions $\mathrm{m} 3, \mathrm{~m} 6$ and $\mathrm{m} 12$, showed a greater accumulation of proline than the tolerant accession (m15) (Hurtado-Salazar, 2016). labal et al. (2016) found that the susceptible wheat cultivar accumulated more proline than the tolerant one. The latter showed higher values of proline in roots, and the first accumulated more proline in shoots. It can be assumed that proline has a similar behavior to abscisic acid (ABA) which, like nicotine, is synthesized in the roots and accumulates in leaves (Kaur \& Zhawar, 2015). In water-saline stress, when the aerial part demands more proline, this is synthesized by roots. Indeed, it should be noted that the proline mechanism of synthesis and accumulation in Passifloraceae are unknown. Further studies are necessary to define the accumulation of proline in Passifloraceae under water-saline stress.

Figure 3 shows that the substrate salinity significantly affected the leaf sodium levels of
Passiflora at 250 days after transplantation (DAT), increasing its values with the enhancement of substrate salinity levels. Leaf sodium content increased significantly with the increase of substrate salinity levels. Thus, it is noted that at 250 DAT there was a tendency to stabilizing sodium values at the highest levels of substrate salinity, which may represent a share at the cellular level, given the lack of identification of the actual location of sodium in the leaf cells studied in this work, reducing the toxicity of this ion in metabolically active sites of the leaves. The sodium concentration increase in shoots of cultivated Passifloraceae in saline environments have been poorly studied. Cruz et al. (2006) also observed increased levels of sodium in yellow passionfruit leaves grown in saline environments. These authors reported that for yellow passionfruit, moderate tolerance is related to maintaining the $\mathrm{N}, \mathrm{P}, \mathrm{Ca}^{++}, \mathrm{Mg}^{++}$concentrations in plant tissues, the ability to confine $\mathrm{Cl}^{-}$ions in roots and $\mathrm{Na}^{+}$in older leaves and maintaining a low $\mathrm{Na}^{+}$: $\mathrm{K}^{+}$ratio in young leaves and roots.

Potassium ions play an important role for regulation of osmotic potential of plant cells and activation of many enzymes involved in respiration and photosynthesis (Taiz \& Zeiger, 2010). In Figure 3, it is evident that the substrate salinity significantly influenced the leaf potassium levels of Passifloraceae at 250 DAT, linearly decreasing its values with the increase of substrate salinity.

Studies have shown that soil salinity decreases potassium levels in plant shoots (Cruz et al., 2006). As in this study, the authors reported that the increase in sodium concentration of the external medium decreases tissue potassium levels of corn (Silva et al., 2016) and yellow passionfruit plants (Cruz et al., 2006), since the increase of sodium concentration in the environment of the root can inhibit the potassium absorption due to the competitive relationship between these monovalent cations. Saline stress increases cytosolic potassium efflux in plant roots; this loss can be the direct result of osmotically induced changes in the permeability of the plasma membrane and the substitution of calcium by sodium in the membrane to open the potassium channel. 
Substrate salinity affected calcium leaf content of the Passifloraceae at 250 DAT (Figure 3). Figure 3 shows the leaf calcium content decrease with the increase of salinity levels of the nutrient solution. Despite the tendency of decrease in leaf calcium content at 250 DAT, the results in this evaluation phase are deemed suitable for accessions m3, m7, m9 and m15 in accordance with the criteria established by Taiz

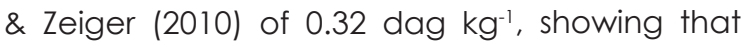
there is a clear relationship between plant growth and nutrient content in its tissues. Accordingly, adequate calcium levels in leaves of Passiflora were high due to the supply of this element by adding this nutrient to the substrate through irrigation water.

According to some studies, salinity decreases the calcium content in shoots of corn (Garcia et al., 2007) and yellow passionfruit plants (Cruz et al., 2006). Similar to this work, these authors reported that the increase in the sodium content of the external environment leads to a reduction of calcium levels in the tissues of corn plants and Passifloraceae, as sodium displaces calcium from the plasmalemma of root cells, resulting in membrane integrity loss and cytosolic output flow of organic and inorganic solutes. Changes in the membrane where calcium is a stabilizing ion can lead to increased sensitivity of the cultivar to saline stress, given the selectivity of the membranes in the processes of absorption and ion compartmentalization (Rizwan et al., 2015).

The determination of the ratios between sodium and calcium, magnesium and potassium $\left(\mathrm{Na}^{+} / \mathrm{Ca}^{++}, \mathrm{Na}^{+} / \mathrm{Mg}^{++}\right.$and $\left.\mathrm{Na}^{+} / \mathrm{K}^{+}\right)$constitute important variables for the selection of salinity tolerant plants and plant nutritional status under saline stress (Garcia et al., 2007). Substrate salinity at 250 DAT interfered significantly the $\mathrm{Na}^{+} / \mathrm{Ca}^{++}$ and $\mathrm{Na}^{+} / \mathrm{Mg}^{++}$ratios in Passifloraceae leaves. Figure 4 shows an increase in the ratios of $\mathrm{Na}^{+} /$ $\mathrm{Ca}^{++}$and $\mathrm{Na}^{+} / \mathrm{Mg}^{++}$in leaves of Passifloraceae with the increase of salinity levels in the nutrient solution. The increase of $\mathrm{Na}^{+} / \mathrm{Ca}^{++}$and $\mathrm{Na}^{+} /$ $\mathrm{Mg}^{++}$leaf ratios with increasing salinity levels in the nutrient solution indicate the increased absorption of sodium at the expense of calcium and magnesium absorption. For accessions m2, $\mathrm{m} 3, \mathrm{~m} 6, \mathrm{~m} 7, \mathrm{~m} 9, \mathrm{ml}, \mathrm{ml} 4$ and $\mathrm{ml} 5$, the $\mathrm{Na}^{+} /$ $\mathrm{Ca}^{++}$and $\mathrm{Na}^{+} / \mathrm{Mg}^{++}$relations at 250 DAT (Figure 4) did not represent the antagonism between nutrients or even showed relative toxicity to ion sodium because such ionic relationships with values below 0.60 are considered suitable for optimal efficiency of metabolism in glycophytes (Ribeiro-Barros et al., 2016).

Maintaining low $\mathrm{Na}^{+} / \mathrm{Ca}^{++}$and $\mathrm{Na}^{+} /$ $\mathrm{Mg}^{++}$proportions is an important criterion for characterizing plant tolerance to salinity (Wang et al., 2014). A high $\mathrm{Na}^{+} / \mathrm{Ca}^{++}$ratio causes $\mathrm{Na}^{+}$ to move to $\mathrm{Ca}^{++}$in cell membrane, leading to a loss of its integrity, resulting in an imbalance in ion absorption and reduction of the selectivity of $\mathrm{Na}^{+} / \mathrm{Ca}^{++}$and $\mathrm{Na}^{+} / \mathrm{Mg}^{++}$in roots (Silva et al., 2016).

The scientific literature shows that an increase in sodium concentration in the root environment promotes elevation ratios of $\mathrm{Na}+$ / $\mathrm{Ca}++$ and $\mathrm{Na}+\mathrm{Mg}^{++}$. In this context, Wang et al. (2014), found an increase in the ratios of $\mathrm{Na}+$ / $\mathrm{Ca}++$ and $\mathrm{Na}+\mathrm{Mg}++$ in the leaf blade, root, stem and pod of corn plants with increased levels of $\mathrm{NaCl}$ in the nutrient solution.

The $\mathrm{Na}^{+} / \mathrm{K}^{+}$ratio is closely related to the degree of salinity crop tolerance; it can be used as an index of sodium toxicity since this ion inhibits the activity of enzymes that require potassium.

Salinity significantly influenced the leaf $\mathrm{Na}^{+} / \mathrm{K}^{+}$ratio of Passifloraceae at $250 \mathrm{DAT}$, as shown in Figure 4, increasing values with increasing substrate salinity levels. Note that $\mathrm{Na}^{+} / \mathrm{K}^{+}$ratio values at 250 DAT (Figure 4) increase linearly with the increase of nutrient solution salinity levels, evidencing the increased absorption and translocation of sodium in relation to the potassium regarding increased salinity levels in the substrate, reflecting culture sensitivity to saline stress and inducing an plant ionic imbalance and consequently, a lower leaf metabolic efficiency.

Garcia et al. (2007) indicated the competitive effect between $\mathrm{Na}^{+}$and $\mathrm{K}^{+}$, and these ions selectivity and their relation to the saline stress plant sensitivity. These authors found an increased shoot $\mathrm{Na}^{+}$and $\mathrm{K}^{+}$ratio of corn plants with the increase of $\mathrm{NaCl}$ levels of the nutrient solution. According to these researchers, the imbalance in ion absorption due to increased ratio of $\mathrm{Na}^{+}$and $\mathrm{K}^{+}$decreases the selectivity 


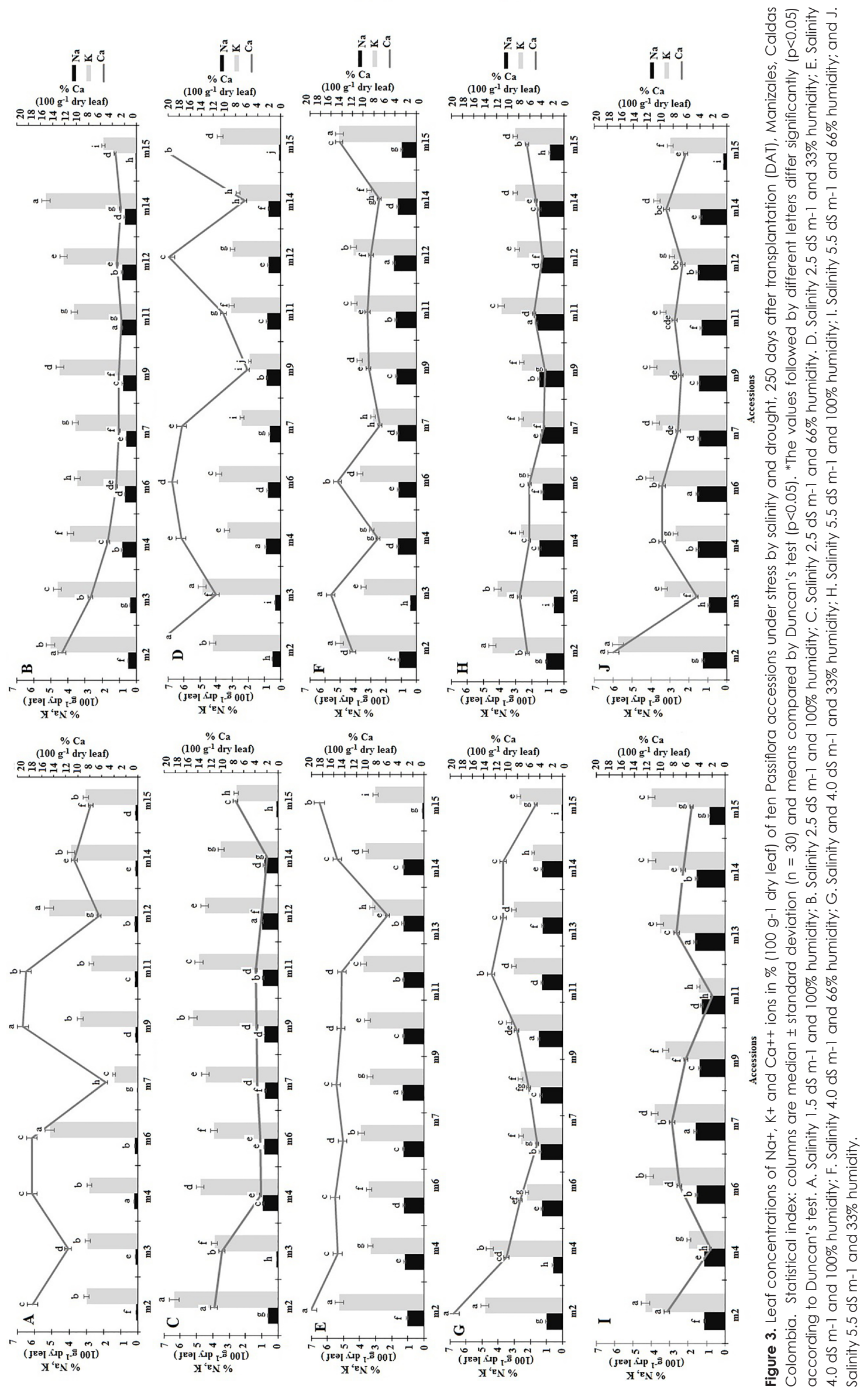

Com. Sci., Bom Jesus, v.8, n.4, p.570-580, Oct./Dec. 2017 


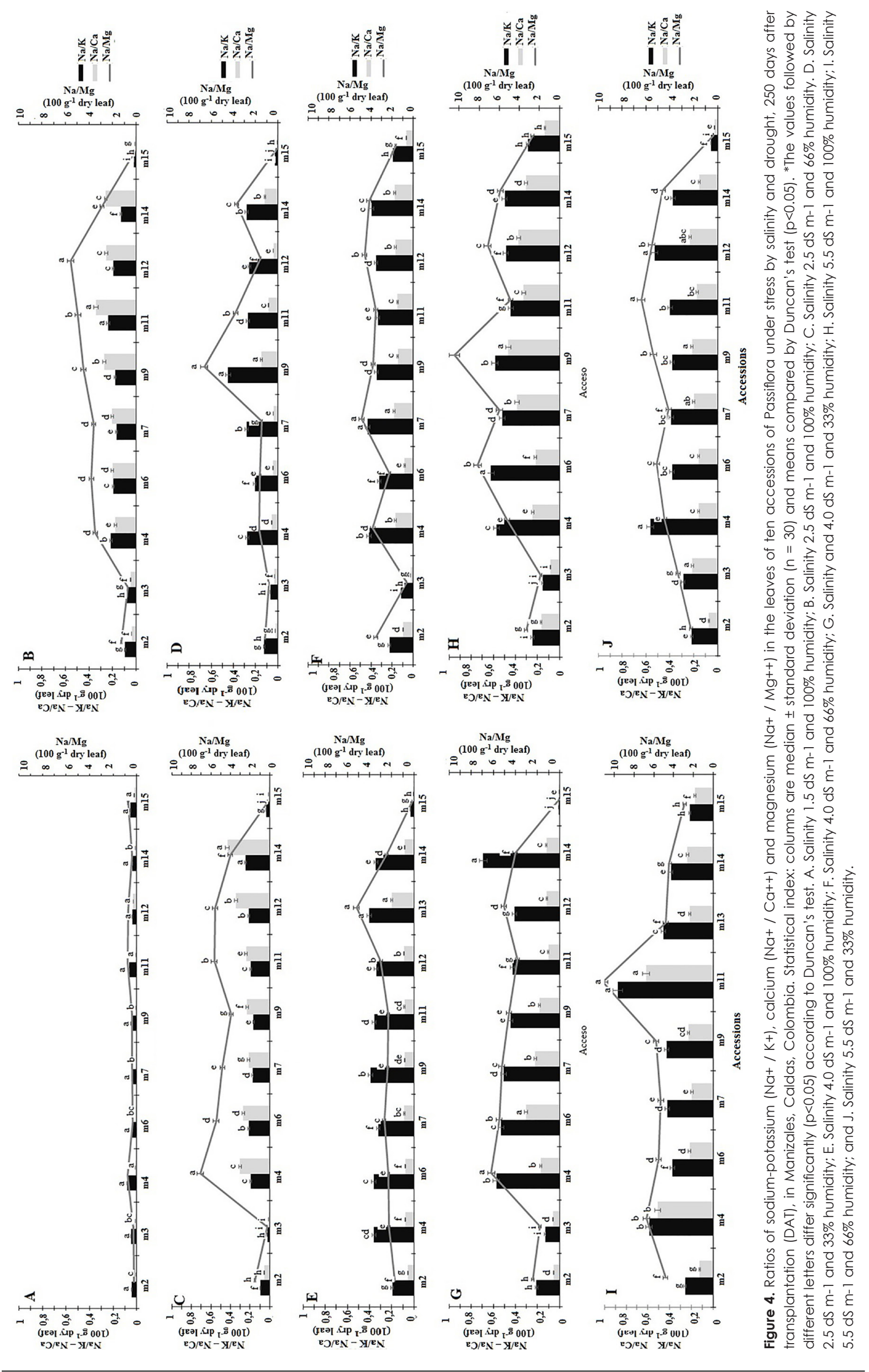

Com. Sci., Bom Jesus, v.8, n.4, p.570-580, Oct./Dec. 2017 
of $\mathrm{K}^{+}$ions in roots due to loss of membrane integrity under saline conditions. Analyzing the leaf content of cationic macronutrients of Passifloraceae throughout the growing season, it is observed that there was a progressive decrease in calcium, magnesium and potassium, together with increased sodium levels. This confirms the hypothesis that the calcium, magnesium and potassium levels decrease in the tissues of Passifloraceae is generally associated with a progressive increase in the sodium content.

\section{Conclusions}

Proline accumulation increased the leaf tissues in response to saline stress, and maximum levels of proline were observed in plants treated with a $\mathrm{NaCl}$ solution with conductivity of $5.5 \mathrm{dS}$ $\mathrm{m}^{-1}$, resulting in higher leaf $\mathrm{Na}^{+}$levels. This result confirms the existence of a relationship between the proline accumulation and ion levels in the tissues.

Sodium leaf levels are high, followed by the reduction of calcium, magnesium and potassium at 250 DAT, reflecting the imbalance caused by nutritional stress consequent of the progressive salinity stress.

The $\mathrm{Na}^{+} / \mathrm{Ca}^{++}, \mathrm{Na}^{+} / \mathrm{Mg}^{++}$and $\mathrm{Na}^{+} / \mathrm{K}^{+}$ leaf concentration ratios increases, proving important variables in nutritional study of plants under saline conditions.

\section{Acknowledgements}

We acknowledge the National Council of Scientific and Technological Development (CNPq), the Coordination of Improvement of Higher Education Personnel (CAPES) and the Foundation for Research Support of the State of Minas Gerais (FAPEMIG) for their financial support.

\section{References}

A.O.A.C. 2016. Official Method of Analysis 20th Edition, Association of Official Analytical Chemists Washington, D. U.S.A.

Abdel, M. 2007. Physiological aspects of mungbean plant (Vigna radiata L. Wilezek) in response to salt stress and gibberellic acid treatment. Research Journal of Agriculture and Biological Sciences 3: 200-213.

Coskun, D., Britto, D.T., Kochian, L.V., Kronzucker, H. J. 2016. How high do ion fluxes go? A re- evaluation of the two-mechanism model of $\mathrm{K}+$ transport in plant roots. Plant Science 243: 96-104.

Cruz, J.L., Pelacani, C.R., Coelho, E.F., Caldas, R.C., De Almeida, A.Q., Queiroz, J.R. 2006. Influência da salinidade sobre o crescimento, absorção e distribuição de sódio, cloro e macronutrientes em plântulas de maracujazeiroamarelo. Bragantia 65(2): 275-284.

Fagiera, N.K., Soares, W., Gheyl. H.R. 2010. Melhoramento genético vegetal e seleção de cultivares tolerantes a salinidade. In: Gheyi. H.R., Dias, N., Lacerda, C.F. (Ed) Manejo da salinidade na agricultura: Estudos básicos e aplicados. Fortaleza: Instituto Nacional de Ciencia e Tecnologia em Salinidade "INCTSal". p. 205-218.

Garcia, G.O., Ferreira, P.A., Miranda, G.V., Neves, J.C.L., Moraes, W.B., Dos Santos, D.B. 2007. Teores foliares dos macronutrientes catiônicos e suas relações com o sódio em plantas de milho sob estresse salino. IDESIA 25(3): 93-106.

Garcia, M., Medina, E. 2009. Acumulación de solutos y solutos orgánicos en dos genotipos de caña de azúcar, estresados con sales simples o suplementadas con calcio. Bioagro 21 (1): 3-14.

Herrera, T.S., Ortíz, J., Delgado, A., Acosta, J.A. 2012. Crecimiento y contenido de prolina y carbohidratos de plántulas de frijol sometidas a estrés por sequía. Revista Mexicana de Ciencias Agrícolas 3(41): 713-725.

Hurtado-Salazar, A. 2016. Tolerância ao estresse abiótico (salinidade e seca) e influência de porta-enxertos na qualidade de frutos em Passiflora spp. 119p. (D.Sc. Thesis) -Federal University of Viçosa, Viçosa, Brazil.

labal, M.J., Maqsood, Y., Abdin, Z.U., Manzoor, A., Hassan, M., Jamil, A. 2016. SSR Markers Associated with Proline in Drought Tolerant Wheat Germplasm. Applied Biochemistry and Biotechnology 5: 1042-1052.

Jian, H., Wang, J., Wang, T., Wei, L., Li, J., Liu, L. 2016. Identification of rapeseed MicroRNAs involved in early stage seed germination under salt and drought stresses. Frontiers In Plant Science 7(article 658).

Kaur, L., Zhawar, V. 2015. Phenolic parameters under exogenous $A B A$, water stress, salt stress in two wheat cultivars varying in drought tolerance. Indian Journal Of Plant Physiology 20(2): 151-156.

Marijuan, M.P., Bosch, S.M. 2013. Ecophysiology of invasive plants: osmotic adjustment and antioxidants. Trends in Plant Science 18: 660-666.

Marin, J.A., Andreu, P., Carrasco, A. Arbeloa, A. 2010. Determination of proline concentration, an abiotic stress marker, in root exudates of excised 
root cultures of fruit tree rootstocks under salt stress. Revue des Régions Arides 24: 722-727.

Niu, F., Zhang, D., Li, Z., Van lersel, M. W., Alem, P. 2015. Morphological response of eucalypts seedlings to phosphorus supply through hydroponic system. Scientia Horticulturae 194295194303.

Ocampo, J., Urrea, R., Wyckhuys, K., Salazar, M. 2013. Exploración de la variabilidad genética del maracuyá (Passiflora edulis f. flavicarpa Degener) como base para un programa de fitomejoramiento en Colombia. Acta Agronómica 62(4): 352-360.

Ribeiro-Barros, A, Da Costa, M., Duro, N., Graça, I., Batista-Santos, P., Ramalho, J., Pawlowski, K. 2016. An integrated approach to understand the mechanisms underlying salt stress tolerance in Casuarina glauca and its relation with nitrogenfixing Frankia Thr. Symbiosis 1-6.

Rizwan, M., Ali, S., Ibrahim, M., Farid, M., Adrees, M., Bharwana, S.A., Abbas, F. 2015. Mechanisms of silicon-mediated alleviation of drought and salt stress in plants: a review. Environmental Science And Pollution Research 20: 15416-15431.

Sacala, E., Demczuk, A., Grzyś, E. 2016. The response of maize seedlings to salt stress under increasing levels of phosphorus. Journal Of Elementology 21 (1): 185-194.

Silva, R.C., Grzybowski, C.R., Panobianco, M. 2016. Vigour in maize seeds: influence on seedling development under conditions of salt stress. Ciência Agronômica 47(3): 491-499.

Statistical Analysis System. 2013. SAS User's guide. SAS Institute, Cary, USA. Version 9.4. CD-ROM

Taiz, L., Zeiger, E. 2010. Plant Physiology, Fifth Edition. Sinaver Associates. Sunderland, USA.. 719 p.

Wang, T., Tian, Q., Wang, B., Zhao, M., Zhang, W. 2014. Genome variations account for different response to three mineral elements between Medicago truncatula ecotypes Jemalong A17 and R108. BMC Plant Biology 14(122): 1-11. 